University of Montana

ScholarWorks at University of Montana

$5-2005$

\title{
An East-West Comparison of Migration in North American Wood Warblers
}

Jeffrey F. Kelly

Richard L. Hutto

University of Montana - Missoula, hutto@mso.umt.edu

Follow this and additional works at: https://scholarworks.umt.edu/biosci_pubs

Part of the Biology Commons

Let us know how access to this document benefits you.

\section{Recommended Citation}

Kelly, Jeffrey F. and Hutto, Richard L., "An East-West Comparison of Migration in North American Wood Warblers" (2005). Biological Sciences Faculty Publications. 272.

https://scholarworks.umt.edu/biosci_pubs/272

This Article is brought to you for free and open access by the Biological Sciences at ScholarWorks at University of Montana. It has been accepted for inclusion in Biological Sciences Faculty Publications by an authorized administrator of ScholarWorks at University of Montana. For more information, please contact

scholarworks@mso.umt.edu. 


\title{
AN EAST-WEST COMPARISON OF MIGRATION IN NORTH AMERICAN WOOD WARBLERS
}

\author{
JEFFREY F. KELLY ${ }^{1,3}$ AND RichaRd L. HutTO ${ }^{2}$ \\ ${ }^{\prime}$ Oklahoma Biological Survey and Department of Zoology, University of Oklahoma, \\ 111 East Chesapeake St., Norman, OK 73019 \\ ${ }^{2}$ Avian Science Center, Division of Biological Sciences, University of Montana, Missoula, MT 59812
}

\begin{abstract}
That western and eastern songbird migration routes are distinct ecological systems has been proposed for over 100 years. Nonetheless, this distinction has not been widely recognized nor have there been any comparative studies that quantitatively evaluate the differences and similarities between western and eastern songbird migration systems. We drew from previously published research on wood warblers to highlight patterns in stopover ecology that suggest fundamental differences between western and eastern migrants. In particular, we compared biogeography, evolutionary relationships, and stopover ecology of wood warblers from western and eastern North America and found: (1) multiple lines of evidence that indicate western wood warblers are geographically isolated from eastern conspecifics or congeners throughout the annual cycle, (2) eastern and western wood warbler taxa are distinct evolutionary units, (3) migrant wood warblers captured in the Southwest tended to carry lower fat loads and be comprised of more after-hatch-year birds than is typical of eastern migrants, (4) frugivory is unknown in wood warblers endemic to the Northwest or Southwest and (5) relative to other regions and seasons, riparian vegetation is heavily used by western wood warblers in the spring. We think that further examination and synthesis of these differences would yield a more mechanistic understanding of NearcticNeotropical avian migration. On this basis, we elaborate our view that (1) an improved understanding of western songbird migration ought to be a high priority for science, conservation, and education, and (2) large-scale coordinated research efforts would be the most effective strategy for advancing our knowledge of passerine migration in the West.
\end{abstract}

Key words: biogeography, frugivory, migration, Parulidae, riparian, stopover ecology, wood warbler.

\section{Una Comparación Este-Oeste de la Migración de las Reinitas de Bosque (Parulidae) de Norte América}

Resumen. Por más de 100 años se ha propuesto que las rutas de migración de aves paseriformes del este y del oeste son sistemas ecológicos diferentes. Sin embargo, esta distinción no ha sido reconocida ampliamente, ni se han realizado estudios comparativos que evalúen cuantitativamente las diferencias y similitudes entre los sistemas de migración del este y del oeste. Revisamos estudios previamente publicados sobre aves de bosque de la familia Parulidae (Reinitas) para destacar los patrones ecológicos de las paradas migratorias que sugieran diferencias fundamentales entre las aves paseriformes migratorias el este y del oeste. Particularmente, comparamos la biogeografía, las relaciones evolutivas y la ecología de las paradas migratorias de las Reinitas del este y del oeste de Norteamérica y encontramos: (1) múltiples líneas de evidencia que indican que las Reinitas del oeste se encuentran geográficamente aisladas de sus coespecíficos o cogenéricos del este durante todo el ciclo anual, (2) los taxa del este y del oeste son unidades evolutivas independientes, (3) las Reinitas migratorias capturadas en el suroeste tendieron a presentar menores cargas de grasa y una mayor proporción de aves eclosionadas durante el año, que lo es típicamente observado para las aves migratorias del este, (4) la frugivoría no se conoce en las Reinitas endémicas del noroeste o sudoeste y (5) en relación a otras regiones o estaciones, la vegetación riparia es usada intensamente durante la primavera por las Reinitas del oeste. Creemos que estudios adicionales y una síntesis de estas diferencias podrían producir un mejor entendimiento mecanístico de la migración Neártico-Neotropical de aves. Basados en esto, sugerimos que (1) un mejor entendimiento de la migración de aves paserinas del oeste debería tener alta prioridad para la ciencia, conservación y educación y (2) que los esfuerzos

Manuscript received 25 August 2004; accepted 26 January 2005.

${ }^{3}$ E-mail: jkelly@ ou.edu 
de investigación coordinados a gran escala serían la estrategia más efectiva para progresar en nuestro conocimiento sobre la migración de las aves paserinas en el oeste.

\section{INTRODUCTION}

Relative to its ecological importance and conservation relevance, the en route phase of the avian annual cycle is poorly known and in need of more research (Hutto 1998). Fortunately, the past two decades have begun to produce the enormous effort that is needed to diminish our ignorance regarding songbird migration in North America. Within the proceedings of the 1977 symposium on migrant birds in the Neotropics, there were no papers on en route migrants (Keast and Morton 1980). By 1989, there were a half-dozen papers in the nonbreeding section of a similar proceedings dedicated to en route migrants (Hagan and Johnston 1992). In the mid-nineties, Moore et al. (1995) published an influential review of the progress of research related to stopover ecology. Finally, in 2000, a volume dedicated entirely to en route migration was published (Moore 2000). Given this growing foundation, we should be in a good position to investigate the intricacies of avian migratory life histories and to apply that knowledge toward avian conservation.

Toward that end, we examined the literature on wood warblers of North America. We assumed that patterns emerging from studies of wood warblers (a single speciose group of North American origin) will serve to illustrate points that apply more broadly. First, we discuss wood warbler phylogeography as it relates to the distinct western migratory pathways proposed a century ago by Cooke $(1904,1915)$. Second, we examine selected literature on stopover ecology to further highlight some fundamental differences in both ecology and our level of knowledge regarding migration in eastern and western North America. Third, we argue that, in terms of benefits for science, education, and conservation, investment in a better understanding of landbird migration in western North America will yield great rewards. Finally, we propose that a large-scale, short-term collaborative research approach would rapidly advance our understanding of en route migration.

\section{COMPARATIVE BIOGEOGRAPHY AND EVOLUTIONARY HISTORY}

Western migration systems are geographically distinct from those in the East. A century ago,

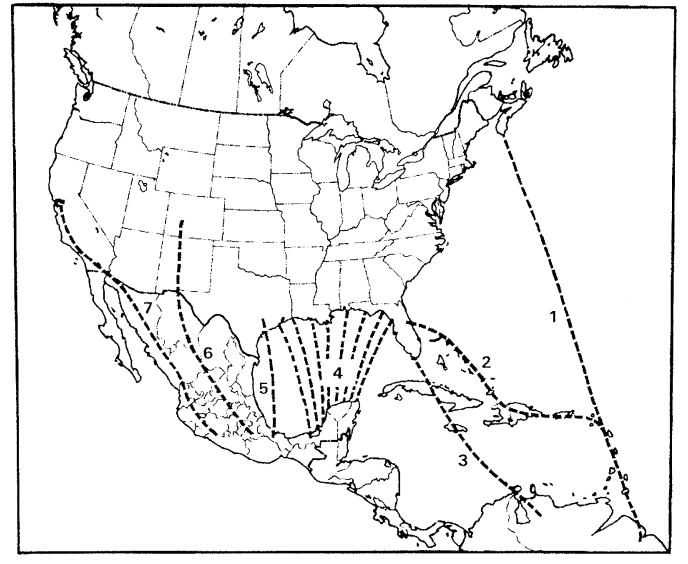

FIGURE 1. Major migrations routes of wood warblers as proposed by W. W. Cooke in 1904. As described by Cooke (1904:8) "These different lines of flight between the southern boundary of the United States and the countries to the south are called in this publication migration routes, but they are not to be considered definite paths with exact boundaries, but merely minor subdivisions of a great migration route that pass insensibly into each other." Map is after Cooke (1915) as illustrated by Wallace and Mannan (1975).

Cooke $(1904,1915)$ presented 7 major subdivisions in the migration pathways used by wood warblers in North America (Fig. 1). All are basically north-south routes, which may seem intuitive, but at least one recent example suggests that some species may deviate from this pattern (Ruegg and Smith 2002). Of Cooke's proposed routes, 5 involve birds that breed in eastern North America and migrate over water to wintering areas in the Caribbean, Latin America, and South America. The remaining migration routes (No. 6 and 7, Fig. 1) involve primarily western species that migrate over land from the interior western U.S. and Canada to the Sierra Madre Oriental or eastern Mexico, and from the Pacific Coast to the Sierra Madre Occidental or Baja California.

Hutto (1985b) quantitatively characterized the breeding and wintering distributions of 50 wood warbler species based on the AOU (1957) checklist of North American Birds and showed that the geographic centers of the breeding ranges of wood warblers are clearly separated into 2 groups-an eastern and a western group (Fig. 2). 


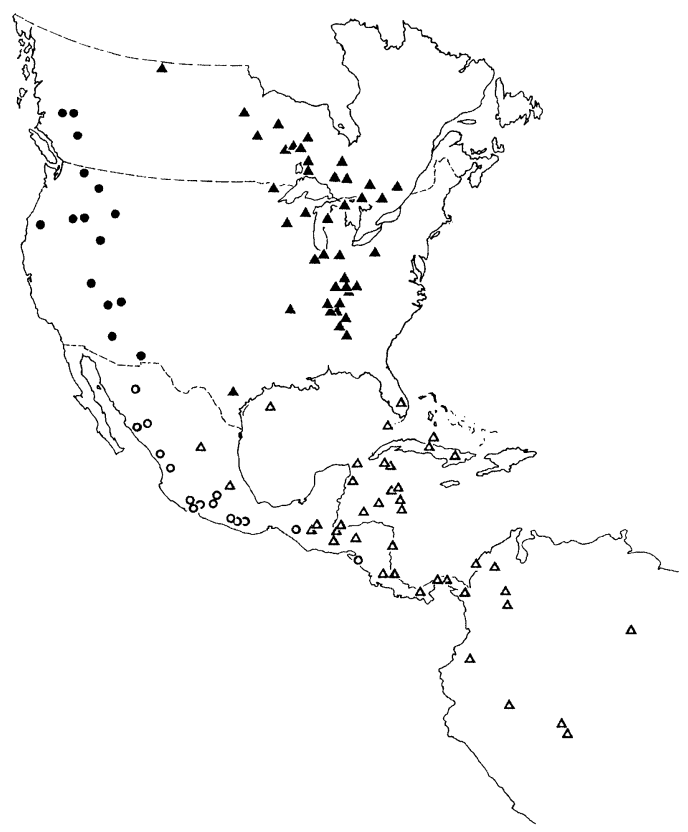

FIGURE 2. The geographic centers of distribution for western (circles) and eastern (triangles) migratory wood warblers during the breeding (filled symbols) and nonbreeding (unfilled symbols) seasons. Reproduced from Hutto 1985b, Fig. 6.

Moreover, plots of the centers of the winter distributions of the same species make it clear that eastern birds remain geographically isolated from western birds in winter as well as summer (Fig. 2).

Using recent range maps available in the Birds of North America species accounts (Poole and Gill, 1992-2003), we categorized 51 species' distributions as being southeastern, boreal, northwestern, southwestern, or widespread (Fig. 3). Only 10 of 51 species were characterized as widespread, with the remaining 41 species being clearly endemic to one of four regions (Appendix). Both the boreal and southeastern regions contained 15 endemics while the southwestern and northwestern regions had relatively few endemic wood warblers $(n=7$ and 4 species, respectively). This categorization also suggests distinct western and eastern migration systems for 41 of the 51 species. What about the 10 widespread species? Five of the species (Yellow Warbler [Dendroica petechia], Wilson's Warbler [Wilsonia pusilla], Common Yellowthroat [Geothlypis trichas], Yellow-breasted Chat [Icteria virens], and Nashville Warbler [Vermivora

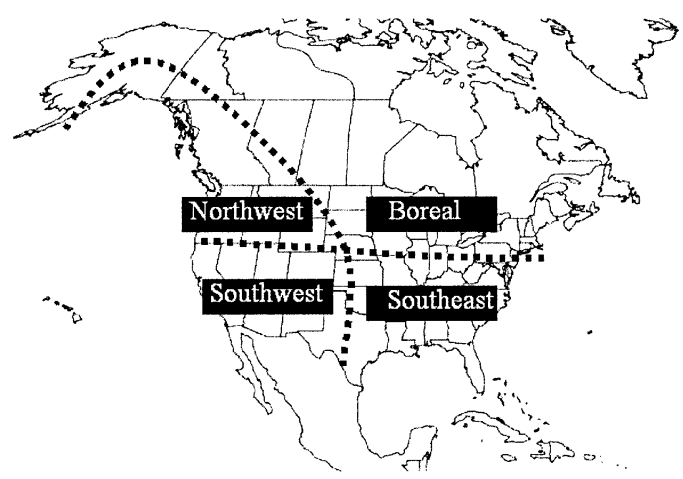

FIGURE 3. Geographic regions to which we assigned 51 wood warbler species distributions. The dividing lines used were (1) south of $40^{\circ} \mathrm{N}$ latitude and either East (southeastern) or West (southwestern) of $100^{\circ} \mathrm{W}$ longitude, and (2) North of $40^{\circ} \mathrm{N}$ latitude and either within and west of the Rocky Mountains (northwestern) and those east of the Rockies (boreal). Species distribution maps were taken from the Birds of North America accounts (Poole and Gill 1992-2003). See Appendix for the names of species assigned to each region.

ruficapilla]) show distinct western and eastern haplotypes using mitochondrial DNA (mtDNA; Milot 2000, Kimura 2000, Lovette et al. 2004). In addition, there have long been western and eastern subspecies (even species at times) described for Ovenbird (Seiurus aurocapillus), Orange-crowned Warbler (Vermivora celata), and Yellow-rumped Warbler (Dendroica coronata, Sogge et al. 1994, Van Horn and Donovan 1994, Hunt and Flaspoler 1998). Thus, of the 51 wood warbler species we examined, only the American Redstart (Setophaga ruticilla, Sherry and Holmes 1997) and the Black-and-whiteWarbler (Mniotilta varia, Kricher 1995) have ranges that straddle the $100^{\text {th }}$ meridian and do not have distinctly described subspecies; both are more abundant in the East. These biogeographic analyses are further corroborated by comparisons of capture rates of species at eastern and western migration sites, which suggest limited species overlap (Kelly et al. 1999). Cooke's $(1904,1915)$ original migration map (Fig. 1), distinct winter geography revealed by Hutto (1985a), and this analysis are all consistent with the proposition that wood warblers use two divergent migratory systems within North America-one eastern and one western. By migration system, we mean a geographic region containing the breeding, migratory and wintering individuals of distinct demographic units. 
Phylogenetic divergence between western and eastern wood warblers. Given that there are distinct eastern and western taxa of wood warblers (see above), what patterns of divergence exist among (1) eastern and western congeners or (2) eastern and western subspecies of more widely distributed species? Recent research in this area of comparative phylogeography has used mtDNA to determine the timing of speciation events with particular reference to the role of glaciation (Hewitt 2000), and interpretation of these data regarding the importance of Pleistocene speciation has been the subject of much debate (Zink and Slowinski 1995, Klicka and Zink 1997, Avise and Walker 1998). Uncertainty reflected by this debate limits our ability to determine which mechanisms are responsible for speciation events: it does not however entirely prevent us from speculating about the relative genetic distinctness of eastern and western wood warblers. We searched for studies that used mtDNA to propose either interspecific or intraspecific phylogenies of North American wood warblers. Not surprisingly, Dendroica warblers were among the best studied of all North American birds in this regard. Lovette and Bermingham (2000) produced a phylogeny based on mtDNA of 24 species of Dendroica. They found that the most recently derived clade within Dendroica comprised the Black-throated Green Warbler (Dendroica virens) complex and Grace's Warbler (Dendroica graciae). Of these 5 species, 4 are western. Bermingham et al. (1992) have shown that the most recent speciation events within the Black-throated Green Warbler complex likely occurred in the West. Within Vermivora, Zink et al. (2000) found that the eastern subspecies of Nashville Warbler (V.ruficapilla ruficapilla) is ancestral not only to the western subspecies (V. ruficapilla ridgwayi), but also to Lucy's Warbler (Vermivora luciae) and Virginia's Warbler (Vermivora virginiae), both of which are western species.

At the intraspecific level, both Klein and Brown (1994) and Milot et al. (2000) have found the greatest support for phylogenies in which Yellow Warblers from western populations are distinct from eastern ancestors. In the Common Yellowthroat mtDNA analyses indicate that western populations are relatively recently derived from eastern subspecies (Ball and Avise 1992). In the MacGillivray's Warbler, Mila et al. (2000) found that western populations were likely the result of post-glacial range expansion of populations in northeastern Mexico Finally, Kimura et al. (2000) used mtDNA to show that western populations of the Wilson's Warbler were distinct from eastern populations.

Overall, of the 11 species we classified as having southwestern or northwestern breeding distributions, mtDNA-based phylogenies indicate that six species (four Dendroica, and two Vermivoras) have undergone relatively recent divergence that resulted in distinct eastern and western taxa (Lovette and Bermingham 1999, Zink et al. 2000). Three other species are restricted to the Southwest and are the sole representatives of their genus in the U.S. (Painted Redstart [Myoborus pictus], Olive Warbler [Peucedramus taeniatus], and Red-faced Warbler [Cardellina rubifrons]). We were also able to locate mtDNA-based phylogenies that surveyed the western and eastern populations for four of ten species that have widespread distributions. All of these phylogenies suggest distinct eastern and western taxa of Wilson's Warbler, Yellow Warbler, Nashville Wabler, and Common Yellowthroats (Ball and Avise 1992, Zink et al. 2000, Milot 2000, Kimura 2000, Lovette et al. 2004). In summary, of the 21 wood warblers that occur in the West, we found mtDNA studies of 11 species. Ten of these studies reported that western taxa were divergent from eastern congeners or conspecifics; the exception was Mila et al. (2000; see above). The consistency of this finding suggests that wood warblers using western migration routes form distinct evolutionary units from those migrating through the East. It seems reasonable to expect that the selection pressure associated with migration in mountainous and arid landscapes have produced novel migratory behaviors and life histories.

Is the migratory connectivity strong or weak in the West? Webster et al. (2002) proposed the notion of connectivity for understanding the degree to which breeding individuals from a given demographic unit are shared by various winter locations and vice versa. For four species of widespread wood warblers, recent mtDNA data suggest that distinct haplotypes of western and eastern breeding wood warblers are closely associated with western and eastern wintering locations, respectively (Kimura et al. 2000, Lovette et al. 2004). In addition, there are indications that within western populations the latitude of the breeding range is associated with that of 
A
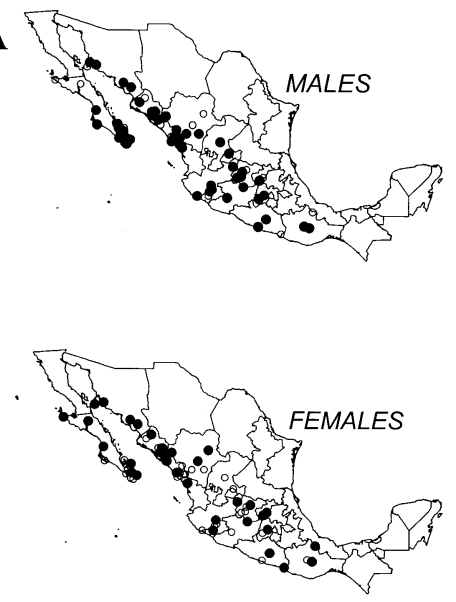

B
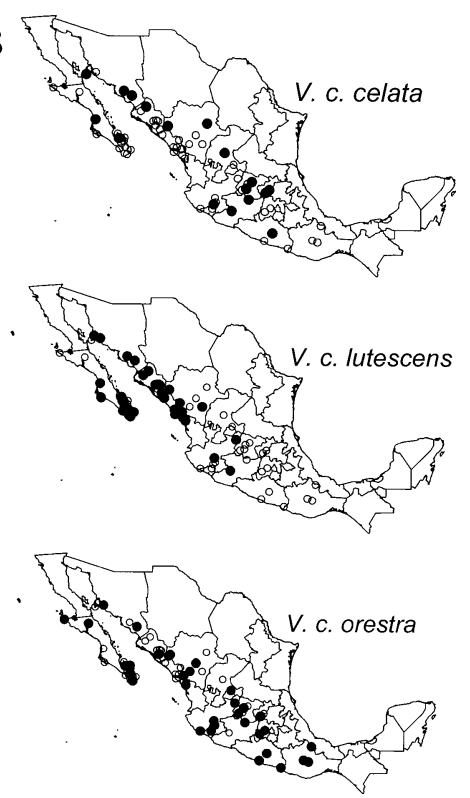

FIGURE 4. The distribution of (A) sexes and (B) three migratory subspecies of Orange-crowned Warbler (Vermivora celata) in Mexico. This example illustrates a lack of clear sexual segregation and a lack of subspecifically based geographical isolation in winter. All collection localities are shown on each map. Filled circles represent localities where at least one specimen of the sex or subspecies shown was collected. Collection localities where no specimen of the sex or subspecies of interest was collected are represented by unfilled circles.

winter residency (Kelly et al. 2002, Clegg et al. 2003). These patterns suggest that when viewed at a broad scale, connectivity is strong. Studies involving mtDNA alone will probably not enable us to resolve whether there are also withinregion patterns of connectivity (Lovette et al. 2004), but there is hope that combining intrinsic markers (e.g., isotopic data and genetic data such as amplified fragment length polymorphisms) will be of considerable use in the future (Bensch et al. 2002; Kelly et al., in press).

Meanwhile, other sources of data can shed light on the degree of connectivity among populations within a migratory system. In 1984, one of us (RLH) examined thousands of specimens at a variety of western museums to determine patterns of winter distribution for all western North American landbird migrant species and subspecies for which there were adequate data. Results of this survey showed that within this species, (1) the two sexes were not obviously segregated geographically in winter, and (2) the various subspecies tended to be well dispersed and intermixed with one another in winter relative to summer where, of course, they are entirely separate (see one example in Figure 4).
Based on these data, it seems likely that a given subspecies can be found most anywhere within the established winter range of its parent species. Similar results were reported by Ramos and Warner (1980) for a local study at Los Tuxtlas, Veracruz, Mexico. In these few cases, connectivity (sensu Webster et al. 2002) between any local breeding population (or geographic unit) and a particular winter location may be weak at the subspecific or population level. There would appear to be no small set of wintering locations for any particular breeding subspecies or population. In such cases, it may be unproductive to search for narrowly defined, geographically based Nearctic-Neotropic conservation partnerships. Whether these patterns are typical for western migrants in unknown. Only further efforts to quantify the seasonal links among geographic localities will allow generalizations to be made about the strength of connectivity among locales in the West. Regardless of the strength of connectivity we should be working to build meaningful international partnerships within a broad geographic framework based on species-wide distribution patterns. 

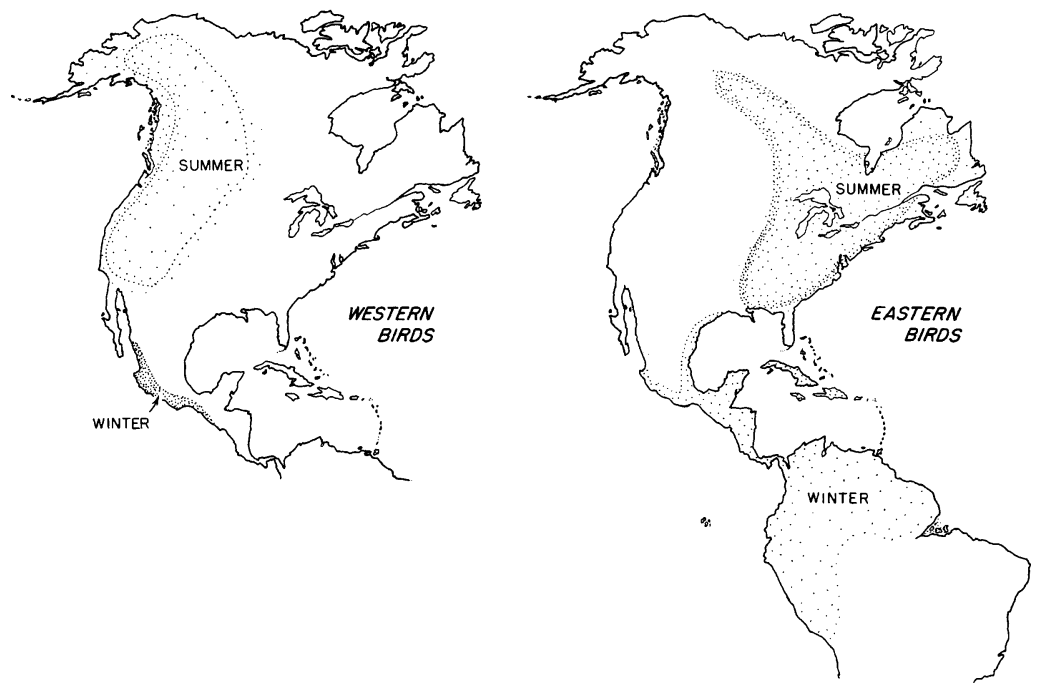

FIGURE 5. Stylized representation of the distributions of eastern and western wood warblers. Note that the in the East the collective breeding ranges are small relative to the collective winter ranges, whereas in the West the collective breeding ranges are large relative to the winter ranges. Figure was originally published on the cover of Finch (1991).

Ramifications of unique geography: seasonal patterns in total area occupied and degree of sympatry. By plotting the breeding and wintering ranges of eastern and western warbler species (defined by the centers of each range as plotted in Fig. 2), it also becomes clear that, in the East, birds collectively occupy a small breeding area relative to the area occupied in winter. In addition, the average number of warbler species that a given eastern warbler species overlaps (to an extent greater than 50\%) is greater in summer than in winter (Hutto 1995). That is, the different eastern warbler species actually spread out from one another a bit in winter relative to summer. Indeed, when MacArthur (1958) went to study his five warbler species in sympatry in Costa Rica winter, he could find only one (Black-throated Green Warbler). The same pattern is true for the Palaearctic-African migration system, and David Lack (1971), who was the first to suggest that coexistence might be promoted by separation of species in winter, noted that most European passerines were more isolated geographically in winter relative to summer. In contrast, in western North America, birds from a relatively large breeding area winter collectively in a relatively small wintering area (Fig. 5), and the average number of warbler species that a given western warbler species overlaps is greater in winter than in summer (Ter- borgh 1980, Cox 1985, Hutto 1995). This pattern appears to be unique among the few migration systems worldwide that have been well studied. The high degree of winter species overlap in the West is correlated with: (1) relatively high densities of wintering birds in many westMexican habitats, (2) broad habitat distributions of bird species that winter in western Mexico, and (3) diverse mixed-species flocks that occur in west-Mexican highlands in winter (Hutto 1980, 1986, 1987, 1995).

\section{AN EAST VS. WEST COMPARISON OF EN ROUTE STOPOVER ECOLOGY}

To this point, we have shown that, at least for wood warblers, the western migration system has geographic, ecological and evolutionary characteristics that make it unique. Consequently, we expect that the migration strategies used by birds in the West might differ from those in the East. As noted earlier, no New World migration system can be described as well studied (Cox 1985). Nonetheless, there are considerably more data available on the stopover ecology of eastern migrants than western migrants. Here, we use the few data that exist from the West to speculate on differences and similarities between stopover ecology in the East and West. The primary metrics we examined were fat scores, age ratios, degree of frugivory, and vegetation as- 
TABLE 1. Means (or modes) of fat score distributions from selected studies of Nearctic-Neotropic migrants captured during fall stopover in the eastern U.S. Sexes were combined in all samples. We only report data for taxa in which $>20$ individuals were measured.

\begin{tabular}{lllll}
\hline \hline \multicolumn{1}{c}{ Taxon } & \multicolumn{1}{c}{ Stopover site } & Age & $\begin{array}{c}\text { Central } \\
\text { tendency }\end{array}$ & \multicolumn{1}{c}{ Source $^{\mathrm{b}}$} \\
\hline Nashville Warbler & Lucky Peak, ID & All & 1.6 & Carlisle et al. 2005 \\
Orange-crowned Warbler & Lucky Peak, ID & All & 2.0 & Carlisle et al. 2005 \\
Black-throated Blue Warbler & Block Island, RI & All & 1.8 & Parrish 1997 \\
American Redstart & Ft. Morgan, AL & AHY & 3.1 & Woodrey and Moore 1997 \\
& Ft. Morgan, AL & HY & 2.4 & Woodrey and Moore 1997 \\
& Appledore Island, ME & All & $0^{\text {c }}$ & Morris et al. 1994 \\
Northern Waterthrush & Appledore Island, ME & All & $1^{\text {c }}$ & Morris et al. 1994d \\
& Block Island, RI & All & 1.5 & Parrish 1997 \\
Ovenbird & Appledore Island, ME & All & $2^{\text {c }}$ & Morris et al. 1994,e \\
Magnolia Warbler & Ft. Morgan, AL & AHY & 3.2 & Woodrey and Moore 1997 \\
& Ft. Morgan, AL & HY & 3.0 & Woodrey and Moore 1997 \\
Yellow-rumped Warbler & Block Island, RI & All & 1.1 & Parrish 1997 \\
& Lucky Peak, ID & All & 1.0 & Carlisle et al. 2005 \\
Yellow Warbler & Lucky Peak, ID & All & 1.3 & Carlisle et al. 2005 \\
Townsend's Warbler & Lucky Peak, ID & All & 2.7 & Carlisle et al. 2005 \\
MacGillivray's Warbler & Lucky Peak, ID & All & 1.1 & Carlisle et al. 2005 \\
Wilson's Warbler & Middle Rio Grande, NM & AHY & 1.0 & Wang et al. 1998 \\
& Middle Rio Grande, NM & HY & 1.0 & Wang et al. 1998 \\
& Lucky Peak, ID & All & 2.7 & Carlisle et al. 2005 \\
\hline
\end{tabular}

\footnotetext{
a Reported value is the mean unless otherwise noted.

${ }^{b}$ Fat was scored on the scale described by Helms and Drury (1960) unless otherwise noted.

c Reported value is the mode.

d Fat was scored on the scale described by Cherry (1982).

e Highest fat score reported was $2+$ and included scores 2 through 6 .
}

sociations. We located as many studies as possible that reported modal or mean fat score and age ratios from en route wood warblers in North America (Table 1). We used Parrish's (2000) review of the incidence of frugivory in migratory birds to assess the relative importance of frugivory to migrants among regions. Petit et al. (1995) and Petit (2000) summarized studies that report migrant use of different vegetation types. We re-examined two of these studies (Parnell 1969, Hutto 1985b) with an emphasis on comparing use of riparian vegetation among regions.

Fat loads. We found data on mean or modal fat scores of 12 wood warblers from 6 authors (Table 1). Kerlinger and Moore (1987) reported fat scores combined across species. Most of these data were from widespread species $(n=$ 7). Other species were boreal (2), northwestern (2), and southeastern (1). Notably, we found no fat score data on any of the species of southwestern warblers, and the only data from stopover sites in the southwestern region were from widespread species. In general, fat scores from the Gulf Coast region of the southeast were higher than those from elsewhere (Table 1). Giv- en the high degree of interobserver variability in scoring fat levels (Kremnetz and Pendelton 1990), we wanted to avoid over interpretation. Consequently, we simply point out that the four highest mean fat scores in the East were from the Gulf Coast. In contrast, in the West the highest fat scores were not reported in the Southwest, but rather from the mountains of Idaho (Table 1). If these few data reflect a general pattern, then it may be that eastern birds carry the most fat in the extreme southern U.S. prior to crossing the Gulf of Mexico, whereas western birds carry the most fat when farthest from their winter destination (or in unpredictable montane environments).

Age ratios. We located age-ratio data for 29 species of wood warblers from stopover sites in the U.S. and Canada. There were data for 21, 22, 6, and 5 species captured in the boreal, southeast, southwest, and northwest regions, respectively. The strongest pattern that emerged from these data was the lack of after-hatch year (AHY) birds in northern and coastal regions. Perhaps due to a coastal effect (sensu Ralph 1971), there tended to be more AHY bird cap- 


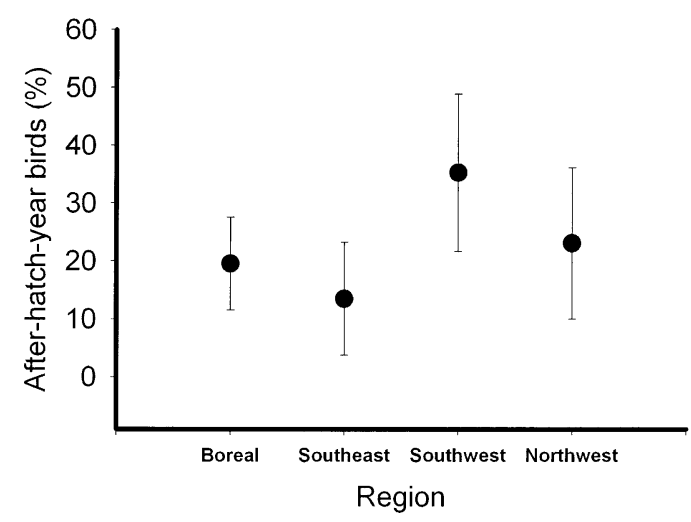

FIGURE 6. Percent of birds (mean \pm SD) captured at bird banding stations that were aged as after-hatchyear. Regions refer to the locations of the banding station. Data are from Jones et al. (2002), Dunn and Nol (1980), Murray (1966), Ralph (1981), Morris et al. (1994), Wang et al. (1998), Wang and Finch (2002), Woodrey and Moore (1997), Ralph (1971), Carlisle et al. (2005), Carlisle et al. (unpubl. data), and Delong et al. (unpubl. data).

tured at sites in the West than in the East (Fig. 6). Most of the eastern data came from Appledore Island (Morris et al. 1994) and Block Island (Parrish 1997) and Long Point Bird Observatory (Dunn and Nol 1980, Jones et al. 2002), all of which catch very few AHY birds. In the West, there were only a few data from Point Reyes and the Farallon Islands (Ralph 1971) where AHY birds comprised less than $5 \%$ of migrants. This factor not withstanding, the highest percentages of AHY wood warblers captured anywhere were reported in the interior southwest (Wang and Finch 2002). If this represents a general pattern, it suggests either that older experienced birds preferentially migrate through the Intermountain West or that coastal populations are more productive than intermountain populations. Either of these scenarios would have a profound impact on management plans for migratory wood warblers.

Frugivory. Levey and Stiles (1992) argued persuasively that frugivory was a likely precursor to migratory life histories in New World birds. Because of evolutionary and ecological implications, frugivory and omnivory have become a focus of migration ecologists. Parrish $(1997,2000)$ has shown that, among passerine migrants, frugivory is a common attribute of species that feed strictly on arthropods during the breeding or winter residency phases of the annual cycle. Morse (1971) suggested that dietary plasticity should be enhanced during migration as a hedge against uncertainty. Consistent with this suggestion, Loria and Moore (1990) showed that migrating Red-eyed Vireos (Vireo olivaceus) increased both their behavioral and mircohabitat range in response to depleted energetic status. Moore (1992) suggested a general relationship between plasticity in foraging behavior and energetic condition of migrating birds. To understand the relative importance of frugivory, and perhaps dietary plasticity, for eastern and western wood warblers, we re-examined Parrish's (2000) review of frugivory in migrants to determine whether the incidence of frugivory was equally distributed across biogeographic regions.

We found a striking difference in the reliance on fruit between eastern and western wood warblers (Table 2). Diet data were available for 39 of 40 species of wood warblers that are boreal, southeastern, or widespread in distribution. Of these, there was evidence of frugivory in 37 species $(95 \%)$. Diet data were only available for seven of the 11 species restricted to the Southwest or Northwest. There was no evidence of frugivory in any of these seven species.

It is important to note that the level of effort expended on documenting frugivory varies widely among species. There can be little doubt that more effort has been invested in diet studies of boreal species than those in the Southwest, which might explain some of the pattern we report. Nevertheless, it is difficult to imagine that frugivory is anywhere near as prevalent in wood warblers in the West as it is in the East. Instead, western wood warblers are much more reliant on arthropod prey during migration than are their eastern counterparts. An important question for understanding migrant ecology would seem to be whether western wood warblers could use fruit, but choose not to because of its availability, distribution, or palatability. Regardless, we expect that this fundamental difference in fuel sources used to power migration should be reflected in the timing, rate of passage, habitat used, and fat loads during migration. Parrish (1997, 2000) has shown that dietary flexibility is a fundamental aspect of migration for eastern species. Given that migrant wood warblers are food limited, at times, in both the East (Moore and Wang 1991) and the West (Kelly et al. 2002), what does the implied lack of dietary 
TABLE 2. Number of wood warbler species for which frugivory has been reported in the literature during the nonbreeding season (overall), within migratory periods, and during winter periods, as reported by Parrish (2000). Degree of frugivory was scored as $0=$ no records or $<5 \%$ of samples in a quantitative study, $+=2$ to 5 records of frugivory or $5 \%$ to $25 \%$ of samples, or $++=$ more than 5 records or greater than $25 \%$ of samples. In situations where a given species was assigned more than one degree of frugivory, we used the highest reported value. Species were divided into regions based on geography of their breeding ranges (see Fig. 5). For species where Parrish (2000) reported no evidence of frugivory, we examined birds of North America (BNA) accounts (Poole and Gill, 1992-2003). We usually could not assign BNA reports of frugivory to a particular season.

\begin{tabular}{|c|c|c|c|c|c|c|c|c|c|c|c|c|}
\hline \multirow[b]{2}{*}{ Region } & \multirow[b]{2}{*}{$n$} & \multirow[b]{2}{*}{ No data } & \multicolumn{3}{|c|}{ Overall } & \multicolumn{3}{|c|}{ Migratory } & \multicolumn{3}{|c|}{ Winter } & \multirow[b]{2}{*}{$\mathrm{BNA}^{\mathrm{a}}$} \\
\hline & & & 0 & + & ++ & 0 & + & ++ & 0 & + & ++ & \\
\hline Southeast & 15 & 1 & 3 & 9 & 2 & 3 & 7 & 1 & 3 & 6 & 1 & $1(4)$ \\
\hline Northeast & 15 & 1 & 0 & 3 & 11 & 0 & 5 & 9 & 5 & 5 & 4 & $1(1)$ \\
\hline Southwest & 7 & 4 & 3 & 0 & 0 & 0 & 0 & 0 & 3 & 0 & 0 & $1(7)$ \\
\hline Northwest & 4 & 0 & 4 & 0 & 0 & 0 & 0 & 0 & 4 & 0 & 0 & $1(4)$ \\
\hline Widespread & 10 & 0 & 0 & 4 & 6 & 0 & 4 & 6 & 6 & 3 & 1 & (0) \\
\hline
\end{tabular}

${ }^{a}$ Number of BNA accounts that mention plants as a diet item (total number of accounts examined in parentheses).

flexibility mean for western migrants? As with many other attributes of western migration, it would be instructive to conduct comparative field experiments to uncover the depth to which this dietary difference affects wood warbler life histories.

Use of vegetation types. A central question in management of migrant landbirds is what determines their distribution and abundance while en route (Petit 2000)? The prevailing hierarchical framework for understanding the habitat selection processes of en route migrants ascribes mechanisms to one of two categories: those processes intrinsic, or those extrinsic to a stopover location (Hilden 1965, Hutto 1985a, Moore et al. 1995). Among the intrinsic site processes, the role of micro- and macrohabitat use and selection has received the majority of attention (reviewed in Petit 2000).

We examined two studies of vegetation use by migrating wood warblers to search for differences between eastern and western species. In particular, we tried to evaluate the relative use of riparian habitats in these different regions. Both Parnell (1969) and Hutto (1985b) defined seven vegetation types within which they surveyed migrants. Parnell's (1969) study took place in the spring in Raleigh, North Carolina. Hutto's (1985a) research was done in spring and fall in the Chiricahua Mountains of southeast Arizona. We considered flood forest to be riparian vegetation in Parnell's (1969) study and creek bottom to be riparian vegetation in Hutto's (1985a). Combined, these studies report abundances of 32 species of wood warblers with 15 in Arizona and 19 in North Carolina. Only Yellow-rumped and Yellow Warblers were observed in both studies. When categorized by breeding distribution there were data on boreal $(n=7)$, southeastern $(n=4)$, southwestern $(n=6)$, northwestern $(n=4)$, and widespread $(n=10)$ species.

The highest percentage of wood warblers found in riparian vegetation overall was during spring migration in the West (Table 3 ). This pattern is not surprising since spring productivity of riparian vegetation in the arid West is considerably greater than that of surrounding uplands. As a result, in part, of monsoonal moisture, the difference in productivity between riparian and upland vegetation in the West is much less marked in late summer and autumn. The differing phenologies of productivity between riparian and upland habitats may contribute to loop migrations, which may be common within the West (Phillips 1975, Hutto 2000). That is, migrants use lowland riparian vegetation for migration during the spring when productivity and temperatures tend to be lower in the higher elevation habitats. In contrast, during the relatively warm dry conditions of fall, migrants may tend to favor migration through higher elevation forest vegetation types. This supposition seems particularly plausible for northwestern wood warblers that showed the largest seasonal shift in use of riparian vegetation between spring and fall (Table 3).

Other patterns in the use of riparian vegetation were that: (1) in the western migration system, wood warblers endemic to the Southwest 
TABLE 3. Percent of wood warblers observed in riparian vegetation. Eastern data were summarized from Raleigh, North Carolina (Parnell 1969). Western data were summarized from the Chiricauhua Mountains, Arizona (Hutto 1985a). Data are reported as mean \pm SD. Samples sizes were the number of species observed. We categorized breeding distributions of wood warblers by region as described in Figure 5.

\begin{tabular}{lccccc}
\hline \hline \multirow{2}{*}{$\begin{array}{c}\text { Breeding } \\
\text { distribution }\end{array}$} & \multicolumn{2}{c}{ West } & & \multicolumn{2}{c}{ East } \\
\cline { 2 - 3 } \cline { 5 - 6 } Southeast & Spring & Fall & $n$ & Spring & $n$ \\
Boreal & & & 0 & $25 \pm 28$ & 7 \\
Southwest & $47 \pm 47$ & $42 \pm 51$ & 6 & $44 \pm 27$ & 4 \\
Northwest & $27 \pm 30$ & $8 \pm 11$ & 4 & & 0 \\
Widespread & $13 \pm 7$ & $9 \pm 9$ & 4 & $13 \pm 12$ & 7 \\
All & $30 \pm 37$ & $20 \pm 34$ & 14 & $25 \pm 24$ & 18 \\
\hline
\end{tabular}

used riparian vegetation heavily in both fall and spring migration seasons, with more than $40 \%$ of all observations recorded from this vegetation type, (2) In the eastern migration system, boreal endemics tended to use riparian vegetation more heavily than southeastern endemics, and (3) Riparian vegetation was used less heavily by widespread species than regional endemics in the West and East.

A number of authors have pointed out the heavy use of riparian habitats by migrants in spring relative to fall in the West (Hutto 1985a, Skagen et al. 1998, Kelly et al. 2000). It is also clear that the fraction of the western landscape that is comprised of riparian habitat is only about $1 \%$, much smaller than in the East, and this small fraction of land has dwindled precipitously in the past two centuries (Knopf et al. 1988, Tellman et al. 1997, Patten 1998, Cartron et al. 2000, Periman and Kelly 2000, Tewksbury et al. 2002). What fraction of migrants depend on the meager portion the western landscape that remains riparian? A simple calculation suggests that if, as Table 3 suggests, $30 \%$ of wood warblers are in riparian vegetation and that vegetation comprises $1 \%$ of the landscape then the density of birds in this vegetation type must be 42 times greater than in the surrounding landscape: (\% of migrants in riparian $* \%$ of landscape that is riparian vegetation $\left.{ }^{-1}\right) *(\%$ of migrants not in riparian vegetation $* \%$ of landscape that is not riparian vegetation $\left.{ }^{-1}\right)^{-1}$. We cannot say with certainty whether this is the case, nor can we say with certainty where the majority of migrants move through the western landscape, which underscores a major problem for developing conservation plans. However, two points are clear: riparian zones are a key to effective conservation of western migrants, and effective conservation will require better data on the spatial scales at which migrants assess and use western landscapes.

Summary. The combined data from phylogeography and stopover ecology suggest that the western migratory system might be unique worldwide in that it is largely an overland affair, comprised of species that are probably very restricted in the locations and habitats used during spring migration, and possibly during fall migration as well. If riparian corridors are used disproportionately frequently in spring, it would mean that an even tinier area than what is shown symbolically on a map might funnel most birds northward.

\section{BIRD MIGRATION: HIGH PRIORITY TOPIC FOR RESEARCH AND EDUCATION}

We think that research in avian migration is among those topics likely to produce truly integrated programs where science is coupled with education in a manner that produces effective conservation results. Future research in this discipline is compelled primarily by two factors inherent to avian migrants. First, the large area that migrant birds traverse within and among seasons makes them natural indicators of hemispheric and global-scale change. While birds and most other organisms can be subjects of local studies of reproduction and survival, only among long-distance migrants are individuals required to adapt to the vastly different regional and global contingencies of human resource consumption and resultant climate trajectories. Long-distance migrants traverse broad spatial scales, but they do so within a relatively short temporal period. This combination of broad spatial and short temporal ecology makes these species among the best natural biotic indicators of 
present and future integrity of landscape and global processes. That these species rely heavily (many exclusively) on riparian habitats in western North America during the breeding and migratory phases of the annual cycle enhances the value of migrants as indicators of riparian condition as well. Consequently, better understanding of avian migratory biology has potential to reveal fingerprints of global change within time frames where management action can be effective. Second, because tracking these small organisms as they move between hemispheres is logistically challenging, avian migration biology continues to foster some of the most important technological innovations in field ecology. For example, advanced applications of satellite telemetry, population genetics, physiology, and biogeochemistry have all been encouraged through studies of the migration ecology of birds.

The scientific rationale for pursing a better understanding of bird migration is strong, and it is matched by migration's value for science education and conservation. The preponderance of private nongovernmental organizations whose primary focus is the conservation of birds is an indication of the political power that migratory birds wield. Finally, because the majority of riparian habitat in the West is in private ownership, effective conservation on those lands will require forward thinking changes to national and international land management policies that promote collaboration and cooperation between private landowners and the public agencies. For example, the Conservation Reserve Program has created millions of acres of grassland habitat for migratory birds on private lands. Such high-level policy decisions are made only when a broad constituency sees value in conservation, and threats to migratory birds are among the few environmental issues that have the strongest potential to influence such policy.

\section{APPROACHES TO ADVANCING OUR UNDERSTANDING OF MIGRATION IN WESTERN NORTH AMERICA}

We still do not know whether relatively few habitats are used by most landbird species during migration. Nonetheless, preliminary data suggest that lowland riparian vegetation constitutes the single-most important habitat in spring. A more definitive understanding of patterns of habitat use during migration are likely to emerge from a coordinated, collaborative research effort, where partners could collect occurrence data from a series of widely scattered sites within only a few years. From simple distributional information that also includes habitat information, we can inform land managers and conservation organizations about where and what habitat conditions we should be targeting for future restoration efforts. Specifically, if we understand the geographic locations and the specific ecological conditions used disproportionately by each species, we will have moved a long way toward their conservation. With emergence and success of coordinated regional monitoring programs, it strikes us that a coordinated research effort in the Southwest might be very productive.

One problem associated with funding a collaborative research effort is that funds available from most conservation and many governmental organizations are earmarked for restoration rather than research. This seems unwise given the fact that we do not even know which places or habitats give us the most return for our conservation effort. Nonetheless, resources have gone largely to on-the-ground restoration efforts in the absence of hard data to guide those efforts because: (1) research biologists have not done a good job educating others about the value of basic research, (2) a false dichotomy between research and monitoring is perpetuated by federal bureaucracy, which limits the effectiveness of both research and monitoring, and (3) research is often without the short-term focus needed to get meaningful results in a matter of years instead of a matter of decades. It is not impossible for a coordinated, collaborative research project to produce meaningful results in a matter of years, but short-term monitoring and swift information transfer must be a high priority and it must be funded as such.

A collaborative effort might be able to confirm whether or not the patterns we outlined above for warblers apply more broadly. If a series of research biologists were situated across the Southwest, for example, and if they conducted surveys at the same time of year in many habitats, they would be able to expose both migratory routes and habitats of importance in only a few years. Coupled with radar surveys and a series of tissue collection protocols across the same area, we could greatly further our knowledge of movement patterns within the West. The power of such a collaborative effort would come 
from being able to attain an enviable level of true treatment replication across meaningful scales, and from the synergism associated with different kinds of research expertise working together.

\section{ACKNOWLEDGMENTS}

We are grateful to S. K. Skagen, R. Hazelwood, and P. Heglund for opportunities to present and refine these ideas at a workshop in Tucson and the 2004 Cooper Ornithological Society Meeting in Lacrosse, WI. We thank D. S. Dobkin, F. R. Moore and T. B Smith for comments on drafts of this manuscript.

\section{LITERATURE CITED}

AMERICAN ORnithologist's Union. 1957. Check-list of North American birds, 5th ed. Allen Press, Lawrence, KS.

AMERICAN ORnithologist's Union. 1998. Check-list of North American birds, 7th ed. Allen Press, Lawrence, KS.

Avise, J. C., AND D. WALKER. 1998. Pleistocene phylogeographic effects on avian populations and the speciation process. Proceedings of the Royal Society of London Series B 265:457-463.

BAll, R. M., AND J. C. AvISE. 1992. Mitochodrial DNA phylogeographic differentiation among avian populations and the evolutionary significance of subspecies. Auk 109:626-636.

Bensch, S., S. ÅKesson, And D. E. Irwin. 2002. The use of AFLP to find an informative SNP: genetic differences across a migratory divide in Willow Warblers. Molecular Ecology 11:2359-2366.

Bermingham, E., S. Rohwer, S. Freeman, and C. Wood. 1992. Vicariance biogeography in the Pleistocene and speciation in North American wood warblers: a test of Mengel's model. Proceedings of the National Academy of Sciences 89: 6624-6628.

Carlisle, J. D., G. S. Kaltenecker, and D. L. SwanSON. 2005. Stopover ecology of the autumn landbird migrant community in the Boise Foothills of southwestern Idaho. Condor 107:244-258.

Cartron, J.-L., S. H. Stoleson, P. L. L. Stoleson, AND D. W. SHAw. 2000. Riparian areas, p. 281328. In R. Jemison and C. Raish [eds.], Livestock management in the American Southwest: ecology, society and economics. Elsevier, Amsterdam, The Netherlands.

Chesser, T., AND D. J. Levey. 1998. Austral migrants and the evolution of migration New World Birds. American Naturalist 152:311-319.

Clegg, S. A., J. F. Kelly, M. Kimura, and T. B. SMITH. 2003. Combining genetic markers and stable isotopes to reveal leapfrog migration in a Neotropical migrant, Wilson's Warbler (Wilsonia pusilla). Molecular Ecology 12:819-830.

Cooke, W. W. 1904. Distribution and migration of North American wood warblers. USDA Bulletin $18: 1-142$

CoOKe, W. W. 1915. Bird migration. USDA Bulletin $185: 1-47$
Cox, G. W. 1985. The evolution of avian migration systems between temperate and tropical regions of the New World. American Naturalist 126:451474.

DunN, E., AND E. Nol. 1980. Age-related migratory behavior of warblers. Journal of Field Ornithology 51:254-269.

FINCH, D. M. 1991. Population ecology, habitat requirements, and conservation of Neotropical migratory birds. USDA General Technical Report RM-205.

Hagan, J. M., III, AND D. W. Johnston [EDs.]. 1992. Ecology and conservation of Neotropical landbird migrants. Smithsonian Institiution Press, Washington, DC.

Hewitt, G. 2000. The genetic legacy of the Quaternary ice ages. Nature 405:907-913.

Hilden, O. 1965. Habitat selection in birds. Annales Zoologici Fennici 2:53-75.

Hunt, P. D., AND D. J. Flaspohler. 1998. Yellow-rumped Warbler (Dendroice coronata). In A. Poole and F. Gill [EDS.], The birds of North America, No. 376. The Birds of North America Inc., Philadelphia, PA.

HutTo, R. L. 1980. Winter habitat distribution of migratory land birds in western Mexico, with special reference to small, foliage gleaning insectivores, p. 181-203. In A. Keast and E. S. Morton [EDS.], Migrant birds in the Neotropics: ecology, behavior, distribution, and conservation. Smithsonian Institution Press. Washington, DC.

HutTo, R. L. 1985a. Seasonal changes in the habitat distribution of transient insectivorous birds in southeastern Arizona: Competition mediated? Auk 102:120-132.

HutTo, R. L. 1985b. Habitat selection by nonbreeding, migratory landbirds, p. 455-476. In M. L. Cody [ED.], Habitat selection in birds. Academic Press, New York.

Hutto, R. L. 1986. Migratory landbirds in western Mexico: a vanishing habitat. Western Wildlands 11:12-16.

Hutto, R. L. 1987. A description of mixed-species insectivorous bird flocks in western Mexico. Condor 89:282-292.

HutTo, R. L. 1995. Can patterns of vegetation change in western Mexico explain population trends in western neotropical migrants?, p. 48-58. In M. H. Wilson and S. A. Sader [EDS.], Conservation of neotropical migratory birds in Mexico. Maine Agricultural and Forest Experiment Station, Misc. Publ. 727.

Hutto, R. L. 2000. On the importance of en route periods to the conservation of migratory landbirds. Studies in Avian Biology 20:109-114.

Jones, J., C. M. Francis, M. Drew, S. Fuller, And M. W. S. NG. 2002. Age-related differences in body mass and rates of mass gain of passerines during autumn migratory stopover. Condor 104: 49-58.

Keast, A., And E. S. Morton [eds.]. 1980. Migrant birds in the Neotropics: ecology, behavior, distribution, and conservation. Smithsonian Institution Press. Washington, DC. 
KeAst, A. 1980. Spatial relationships between migratory Parulid warblers and their ecological counterparts in the Neotropics, p. 109-132. In A. Keast and E. S. Morton [EDS.], Migrant birds in the Neotropics: ecology, behavior, distribution and conservation. Smithsonian Institution Press, Washington, DC.

Kelly, J. F., V. Atudorei, Z. D. Sharp, and D. M. FINCH. 2001. Insights into Wilson's Warbler migration from analyses of hydrogen stable-isotope ratios. Oecologia 130:216-221.

Kelly, J. F., L. S. DeLay, and D. M. Finch. 2002. Density dependent mass gain in Wilson's Warbler during stopover. Auk 119:210-213.

Kelly, J. F., D. M. Finch, And W. Yong, 2000. Vegetative associations of wood warblers migrating along the Middle Rio Grand Valley, New Mexico. Southwestern Naturalist 45:159-168.

Kelly, J. F., R. Smith, D. M. Finch, F. R. Moore, And W. YONG. 1999. Influence of summer biogeography on wood warbler stopover abundance. Condor 101:76-85.

Kimura, M., S. M. ClegG, I. J. Lovette, K. R. Holder, D. J. Girman, B. Milá, P. Wade, and T. B. SMITH. 2002. Phylogeographic approaches to assessing demographic connectivity between breeding and overwintering regions in a Nearctic-Neotropical warbler (Wilsonia pusilla). Molecular Ecology 11:1605-1616.

Klein, N., AND W. M. BRown. 1994. Intraspecific molecular phylogeny in the Yellow Warbler (Dendroica petechia), and implications for avian biogeography in the West Indies. Evolution 48:19141932.

KLICKA, J., AND R. M. ZINK. 1997. The importance of recent ice ages in speciation: a failed paradigm. Science 277:1666-1669.

Knopf, F. L., R. R. Johnson, T. Rich, F. B. SAmson, AND R. C. Szaro. 1988. Conservation of riparian ecosystems in the United States. Wilson Bulletin 100:272-284.

Kremnetz, D. G., and G. W. Pendelton. 1995. Fat scoring: sources of variability. Condor 92:500508.

KRICHER, J. 1985. Black-and-white Warbler (Mniotilta varia). In A. Poole and F. Gill [EDS.], The birds of North America, No.158. The Academy of Natural Sciences, Philadelphia, PA, and The American Ornithologist's Union, Washington, DC.

LACK, D. 1971. Ecological isolation in birds. Harvard University Press, Cambridge, MA.

Levey, D. J., AND F. G. StILES. 1992. Evolutionary precursors of long-distance migration: resource availability and movement patterns in Neotropical landbirds. American Naturalist 140:447-476.

LORIA, D. L., AND F. R. MOORE. 1990. Energy demands of migrating Red-eyed Vireos, Vireo olivaceus. Behavioral Ecology 1:24-35.

Lovette, I. J., AND E. Bermingham. 1999. Explosive speciation in New World Dendroica warblers. Proceedings of the Royal Society of London Series B 266:1629-1636.

Lovette, I. J., S. M. ClegG, And T. B. Smith. 2004. Limited utility of mtDNA markers for determining connectivity among breeding and overwintering locations in three Neotropical migrant birds. Conservation Biology 18:156-166.

MacArthur, R. H. 1958. Population ecology of some warblers of northeastern coniferous forests. Ecology 39:599-619.

Milá, B., D. J. Girman, M. Kimura, and T. B. Smith. 2000. Genetic evidence for the effect of a postglacial population expansion on the phylogeography of a North American songbird. Proceedings of the Royal Society of London Series B 267: 1033-1040.

Milot, E. M., H. L. GibBs, And K. A. Hobson. 2000. Phylogeography and genetic structure of northern populations of the Yellow Warbler (Dendroica petechia). Molecular Ecology 9:667-681.

Moore, F. R. 1992 Ecophysiological and behavioral response to energy demand during migration. Acta Congressus Intenationalis Onthilogici 20:753760 .

Moore, F. R. [ED.]. 2000. Stopover ecology of Nearctic-Neotropical landbird migrants: habitat relations and conservation implications. Studies in Avian Biology No. 20.

Moore, F. R., S. A. Gauthreaux JR., P. Kelinger, And T. R. SimONS. 1995. Habitat requirements during migration: important link in conservation, p. 121144. In T. E. Martin and D. M. Finch [EDS.], Ecology and management of Neotropical migratory birds. Oxford University Press, New York.

Moore, F. R., AND P. KerLinger. 1987. Stopover and fat deposition by North American wood warblers (Parulinae) following spring migration over the Gulf of Mexico. Oecologia 74:47-54.

Moore, F. R., AND Y. WANG. 1991. Evidence of foodbased competition among passerine migrants during stopover. Behavioral Ecology and Sociobiology 28:85-90.

Morris, S. R., M. E. Richmond, And D. W. Holmes. 1994. Patterns of stopover by warblers during spring and fall migration on Appledore Island, Maine. Wilson Bulletin 106:703-718.

MorSE, D. H. 1971. The insectivorous bird as an adaptive strategy. Annual Review of Ecology and Systematics 2:177-200.

Murray, B. G. 1966. Migration of age and sex classes of passerines on the Atlantic coast in autumn. Auk 88:352-360.

PARnell, H. F. 1969. Habitat relations of the Parulidae during spring migration. Auk 86:505-521.

PARRISH, J. D. 1997. Patterns of frugivory and energetic condition in Nearctic landbirds during autumn migration. Condor 99:681-697.

PARRISH, J. D. 2000. Behavioral, energetic and conservation implications of foraging plasticity during migration. Studies in Avian Biology 20:53-70.

Patten, D. T. 1998. Riparian ecosystems of semi-arid North America: diversity and human impacts. Wetlands 18:498-512.

Periman, R. D., And J. F. Kelly. 2000. The dynamic environmental history of southwestern Willow Flycatcher habitat: a survey of changing riparian conditions through time, p. 25-42. In S. H. Stoleson and D. M. Finch [EDS.], Status, ecology, and 
conservation of the southwestern Willow Flycatcher. USDA General Technical. Report RMRSGTR-60.

Petit, D. R. 2000. Habitat use by landbirds along Nearctic-Neotropical migration routes: implications for conservation of stopover sites. Studies in Avian biology 20:15-33.

Petit, D. R., R. B. Waide, R. L. Hutto, J. F. Lynch, AND J. G. BlaKe. 1995. Habitat use and conservation of migratory landbirds overwintering in the Neotropics, p. 145-197. In T. Martin and D. M. Finch [EDS.], Ecology and management of Neotropical migratory birds. Oxford University Press, New York.

PhILlIPS, A. R. 1975. The migrations of Allen's and other hummingbirds. Condor 77:196-205.

Poole, A., AND F. B. GILl [EDS.]. 1992-2003. The birds of North America. The Birds of North America, Inc., Philadelphia, PA.

RALPH, C. J. 1971. Age differential of migrants in coastal California. Condor 73:243-246.

RalPh, C. J. 1981. Age ratios and their possible use in determining autumn migration routes of passerine migrants. Wilson Bulletin 93:164-188.

RAmos, M. A., AND D. W. WARNER. 1980. Analysis of North American subspecies of migrant birds wintering in Los Tuxlas, southern Veracruz, Mexico, p. 173-180. In A. Keast and E. S. Morton [EDS.] Migrant birds in the Neotropics: ecology, behavior, distribution, and conservation. Smithsonian Institution Press, Washington, DC.

RuegG, K. C., AND T. B. Smith. 2002. Not as the crow flies: an historical explanation for circuitous migration in the Swainson's Thrush (Catharus ustulatus). Proceedings of the Royal Society of London Series B. 269:1375-1381.

Scott, M. L., S. K. Skagen, and M. F. Merigliano. 2003. Relating geomorphic change and grazing to avian communities in riparian forests. Conservation Biology 17:284-296.

Sherry, T. W., AND R. T. Holmes. 1997. American Redstart (Setophaga ruticilla). In A. Poole and F. Gill [EDS.], The birds of North America, No.277. The Academy of Natural Sciences, Philadelphia, PA, and The American Ornithologists' Union, Washington DC.

Skagen, S. K., C. P. Melcher, W. H. Howe, and F. L. KNOPF. 1998. Comparative use of riparian corridors and oases by migrating bird in southeast Arizona. Conservation Biology 12:896-910.

Sogge, M. K., W. M. Gilbert, and C. Van Riper III. 1994. Orange-crowned Warbler (Vermivora celata). In A. Poole and F. Gill [EDS.], The birds of North America, No.101. The Academy of Natural
Sciences, Philadelphia, PA, and The American Ornithologists' Union, Washington DC.

Tellman, B., R. Yarde, and M. G. Wallace. 1997. Arizona's changing rivers: how people have affected the rivers. Issue Paper No. 19. Water Resources Center, College of Agriculture, University of Arizona, Tucson, AZ.

Terborgh, J. W. 1980. The conservation status of Neotropical migrants: present and future, p. 21-30. In A. Keast and E. S. Morton [EDS.] Migrant birds in the Neotropics: ecology, behavior, distribution and conservation. Smithsonian Institution Press, Washington DC.

Tewksbury, J. J., A. E. Black, N. Nur, V. A. SaAb, B. D. Logan, AND D. S. Dobkin 2002. Effects of anthropogenic fragmentation and livestock grazing on western riparian bird communities. Studies in Avian Biology 25:158-202.

VAn Horn, M. A., AND T. M. Donovan. 1994. Ovenbird (Seirus aurocapillus). In A. Poole and F. Gill [EDS.], The birds of North America, No. 88. The Academy of Natural Sciences, Philadelphia, PA, and the American Ornithologist's Union, Washington DC.

Wallace, G. J., and H. D. Mahan. 1975. An introduction to ornithology, 3rd ed. MacMillan Publishing, Co., Inc., New York.

WANG, Y., AND D. M. FInCH. 2002. Stopover ecology of landbirds migrating along the middle Rio Grande in spring and fall. USDA General. Technical. Report. RMRS-GTR-99. USDA, Ogden, UT.

Wang, Y., D. M. Finch, F. R. Moore, And J. F. Kelly. 1998. Stopover ecology and habitat use of migratory Wilson's Warblers. Auk 115:829-842.

Webster, M. S., P. P. Marra, S. M. Haig, S. Bensch, AND R. T. Holmes. 2002. Links between worlds: unraveling migratory connectivity. Trends in Ecology \& Evolution 17:76-83.

Woodrey, M. S., AND F. R. Moore. 1997. Age-related timing differences in stopover of fall landbird migrants on the coast of Alabama. Auk 114:695707.

ZINK, R. M. 1996. Comparative phylogeography in North American Birds. Evolution 50:308-317.

ZINK, R. M., R. C. Blackwell-Rago, and F. RonQUIST. 2000. The shifting roles of dispersal and vicariance in biogeography. Proceedings of the Royal Society of London Series B 267:497-503

ZINK, R. M., AND J. B. SLowInSKI. 1995. Evidence from molecular systematics for decreased avian diversification in the Pleistocene Epoch. Proceedings of the National Academy of Sciences 92: 5832-5835. 
APPENDIX. Species names of wood warblers and region of endemism within North America.

\begin{tabular}{|c|c|}
\hline Species & Breeding region \\
\hline Olive Warbler (Peucedramus taeniayus) & Southwest \\
\hline Bachman's warbler (Vermivora bachmanii) & Southeast \\
\hline Blue-winged Warbler (V.pinus) & Southeast \\
\hline Golden-winged Warbler (V. chrysoptera) & Southeast \\
\hline Tennessee Warbler $(V$. peregrina $)$ & Boreal \\
\hline Orange-crowned Warbler $(V$. celata $)$ & Widespread \\
\hline Nashville Warbler (V. ruficapilla) & Widespread \\
\hline Virginia's Warbler (V. virginiae) & Southwest \\
\hline Colima Warbler (V. crissalis) & Southwest \\
\hline Lucy's Warbler (V. luciae) & Southwest \\
\hline Northern Parula (Parula americana) & Southeast \\
\hline Yellow Warbler (Dendroica petechia) & Widespread \\
\hline Chestnut-sided Warbler (D. pensylvanica) & Boreal \\
\hline Magnolia Warbler (D. magnolia) & Southeast \\
\hline Cape-May Warbler (D. tigrina) & Boreal \\
\hline Black-throated Blue Warbler (D. caerulescens) & Boreal \\
\hline Yellow-rumped Warbler $(D$. coronata $)$ & Widespread \\
\hline Black-throated Gray Warbler (D. nigrescens) & Northwest \\
\hline Golden-cheeked Warbler (D. chrysoparia) & Southeast \\
\hline Black-throated Green Warbler (D. virens) & Boreal \\
\hline Townsend's Warbler (D. townsendi) & Northwest \\
\hline Hermit Warbler (D. occidentalis) & Northwest \\
\hline Yellow-throated Warbler (D. dominica) & Southeast \\
\hline Grace's Warbler (D. graciae) & Southwest \\
\hline Pine Warbler (D. pinus) & Southeast \\
\hline Kirtland's Warbler (D. kirtlandii) & Boreal \\
\hline Prairie Warbler (D. discolor) & Southeast \\
\hline Palm Warbler (D. palmarum) & Boreal \\
\hline Bay-breasted Warbler (D. castanea) & Boreal \\
\hline Blackpoll Warbler (D. striata) & Boreal \\
\hline Blackburnian Warbler (D. fusca) & Boreal \\
\hline Cerulean Warbler $(D$. cerulea $)$ & Southeast \\
\hline Black-and-white Warbler (Mniotilta varia) & Widespread \\
\hline American Redstart (Setophaga ruticilla) & Widespread \\
\hline Prothonotary Warbler (Protonotaria citrea) & Southeast \\
\hline Worm-eating Warbler (Helmitheros vermivorus) & Southeast \\
\hline Swainson's Warbler (Limnothlypis swainsonii) & Southeast \\
\hline Ovenbird (Seiurus aurocapillus) & Widespread \\
\hline Northern Waterthrush (S. noveboracensis) & Boreal \\
\hline Louisiana Waterthrush (S. motacilla) & Southeast \\
\hline Kentucky Warbler (Oporornis formosus) & Southeast \\
\hline Connecticut Warbler (O. agilis) & Boreal \\
\hline Mourning Warbler (O. philadelphia) & Boreal \\
\hline MacGillivray's Warbler (O. tolmiei) & Northwest \\
\hline Common Yellowthroat (Geothlypis trichas) & Widespread \\
\hline Hooded Warbler (Wilsonia citrina) & Southeast \\
\hline Wilson's Warbler (W. pusilla) & Widespread \\
\hline Canada Warbler (W. canadensis) & Boreal \\
\hline Red-faced Warbler (Cardellina rubrifrons) & Southwest \\
\hline Painted Redstart (Myioborus pictus) & Southwest \\
\hline Yellow-breasted Chat (Icteria virens) & Widespread \\
\hline
\end{tabular}

